\title{
Improving The Quality of Learning through Lesson Study Model Based on Innovation Class in SMPN 2, Menganti Gresik District
}

\author{
Supriyono \\ SMPN 2 Menganti, Gresik \\ e-mail: supriyonosupri64@yahoo.com
}

\begin{abstract}
This study aims to determine the improvement of the quality of learning through the innovationbased class lesson study model school program. Research was conducted in three stages, namely: plan, do, see, for students in grades 7, 8, and 9. Techniques for collecting data through observation, and reporting. Data analysis was done in a qualitative, discrete manner. The results of the study showed the involvement of students, model teachers, teacher observers, Dispendik supervisors, committees and principals, parents / guardians of students and invitations from other schools were very active. Thus, improving the quality of learning through the innovation class based lesson study model school program has been very successful in improving the quality of expected learning.
\end{abstract}

Keywords : Lesson study, Innovation class, Quality of learning

\section{INTRODUCTION}

As in Government Regulation Number 19 of 2005, Article 19, paragraph 1 states that the learning process in educational units is held interactively, inspiring, fun, challenging, motivating students to actively participate, and providing sufficient space for initiative, creativity, in accordance with the talents, interests, and physical and psychological development of students. In the Teacher and Lecturer Law it is stated that a teacher must have pedagogical competence, professional competence, personality competence and social competence. In pedagogical and professional competencies, the teacher is expected to be able to study each lesson so that the learning done is more meaningful. Most teachers work individually unwillingly to be entered by others when conducting teaching and learning activities. One effort to guide teachers is the Implementation of Permenpan No. 16 of 2009 concerning efforts to improve the quality of learning oriented to an effort to improve student learning outcomes.

Learning success is determined by many supporting factors, but the biggest is the teacher. With quality learning, the teacher will be able to make the achievements of his students to improve. The problem is that not all teachers are continuous and comprehensive to study their learning. One effective way to study learning is to use lesson study. Lesson study selected and implemented the separate due to several reasons including:

The reason for using lesson study, first, lesson study is an effective way that can improve the quality of teacher teaching and learning activities of students. This is true, because (1) the development of lesson study conducted and based on the "sharing" of professional knowledge based on practice and learning outcomes undertaken by the teachers, (2) fundamentally a lesson study is the learners have the quality of learning, (3) lesson objectives are used as the focus and main focus in classroom learning, (4) based on real experience in the classroom, lesson study can become the basis for the development of learning, and (5) lesson study will place the role of teachers as learning researchers (Lewis, 2002). 
The Second reason, lesson study designed well will produce teachers who are professional and innovative. By implementing lesson study teachers can (1) determine objectives, lesson, unit subjects, and subjects were effective; (2) study and improve lessons that are useful for students; (3) make deeper knowledge of the subjects presented by the teacher; (4) determine long-term goals to be achieved by the learners; (5) planning distance collaboratively; (6) examine carefully the learning and behavior of students; (7) develop reliable learning knowledge; and (8) do reflection on the implementation of teaching based on the views of learners and colleagues (Lewis, 2002)

Wang-Iverson and Yoshida (2005) say that lesson study has several benefits as follows : reducing teacher alienation (from the community), helping teachers to observe and criticize their learning, deepening teacher's understanding of subject matter, scope and sequence of curriculum, helping teachers focus their help on all student learning activities, creating an exchange of expectations for students' understanding of thinking and learning, increase collaboration attention to fellow teachers.

Table 1. Stage Of The Lesson Study

\begin{tabular}{|c|c|c|}
\hline $\begin{array}{l}\text { - Planning } \\
\text { - Academic excavation } \\
\text { - Learning planning } \\
\text { - Preparation of tools }\end{array}$ & $\begin{array}{l}\text { - Implementation } \\
\text { - Implementation of } \\
\text { learning } \\
\text { - Observations by } \\
\text { colleagues }\end{array}$ & $\begin{array}{l}\text { - Seeing } \\
\text { - Reflection with } \\
\text { colleagues } \\
\text { - Comments and } \\
\text { discussions }\end{array}$ \\
\hline
\end{tabular}

Study of Practice-Oriented Learning (Saito et al. 2005)

\section{Quality of Learning}

Opinion Mr. Masaaki Sato: The occurrence of a collapsed school lies in the teacher generally think that they are the most powerful in the class, the most intelligent and have experienced many years and make students graduate with good pridikat. The irony is that the smartest, most correct, and most powerful teacher doesn't want to be observed by others when teaching.

Quality of learning enables students to have control over their own learning. They know how to self regulate and reflect on their learning. They know how our brains function and are able to understand the process of learning which is made explicit to them.

\section{Innovation Class Based Lesson Study}

Provide opportunities for teachers to be willing to implement Open Class, provide opportunities for teachers to be observed by their peers or by the Principal / Supervisor, to improve the quality of learning for teachers by learning from their fellow teachers, to form collegiality by collaborating together, aims to develop inter-teacher collaborative relationships to create "effective schools". Therefore, it is important to form a common understanding between teachers regarding pedagogical learning and practices that are appropriate and meet the needs of students. 


\section{RESEARCH METHODS}

\section{A. Innovation Group and Time}

The method of implementation innovation class used based lesson study, first making subjects teacher group. In State Middle School 2, Menganti have maked subjects teacher groups. There are 13 groups B.

Table 2. Teacher Groups

\begin{tabular}{|c|c|c|c|}
\hline No & Subjects & Leader & Members \\
\hline 1 & Relegion & $\begin{array}{l}\text { Nurul Huda, S.Ag., } \\
\text { M.Si }\end{array}$ & $\begin{array}{l}\text { Ainul Yaqin, S.Ag } \\
\text { Hj. Nur ayati, S.Pd., } \\
\text { M.Pd } \\
\text { Syaifuddin Zuhri, S.Pd }\end{array}$ \\
\hline 2 & Civic & Kasin, S.Pd & $\begin{array}{l}\text { K a s i n, S.Pd } \\
\text { Ida Oelfijah, S.Pd } \\
\text { Hj. Nur Ayati, S.Pd,M.Pd }\end{array}$ \\
\hline 3 & $\begin{array}{l}\text { Indonesian } \\
\text { Language }\end{array}$ & Nuriyasih, S.Pd & $\begin{array}{l}\text { Musta'in, S.Pd } \\
\text { Anthoneta , M.Pd } \\
\text { Dra. Marminah } \\
\text { 4. El Yakim, S.Pd }\end{array}$ \\
\hline 4 & Math & Drs. A n w a r & $\begin{array}{l}\text { Djoemadi, S.Pd, M.Pd } \\
\text { Nur Indah, S.Pd, M.Pd } \\
\text { Abdul Manaf,S.Pd } \\
\text { Linda Dwi, S.Pd }\end{array}$ \\
\hline 5 & Science & Titik Ngatmi R, M.Pd & $\begin{array}{l}\text { Siti Laila, S.Pd } \\
\text { Drs. Heru Subagyo,MPd } \\
\text { Gianto, S.Pd, M.Pd } \\
\text { Vita Yuanita, S.Pd } \\
\text { Amalia Citra, S.Pd } \\
\end{array}$ \\
\hline 6 & Social Science & $\begin{array}{l}\text { Endang Susilowati, } \\
\text { M.Pd }\end{array}$ & $\begin{array}{l}\text { Anies M.,S.Pd,M.Pd } \\
\text { Kasiati, S.Pd } \\
\text { Tri Wahyu ,S.Pd,M.Pd } \\
\text { Sunanto, S.Pd } \\
\text { Dra. Sudartik } \\
\end{array}$ \\
\hline 7 & Sport & M. Sofwan, S.Pd & $\begin{array}{l}\text { Drs.Imam Mahdi } \\
\text { Mursid Wicaksono, S.Pd }\end{array}$ \\
\hline 8 & English & Ririn Indra K., S.Pd & $\begin{array}{l}\text { Andis Erika, S.Pd } \\
\text { Mas'adatul Faridah, S.Pd } \\
\text { Ingrelia Apriyani, S.Pag } \\
\text { Amalia Kurniatul J., S.Pd }\end{array}$ \\
\hline 9 & Art and Cultur & Drs. Puji Herwanto & Iman Gunawan, S.Pd \\
\hline 10 & Cullinary art & Isang Yanuar B., S.Pd & Tamamik, S.Pd \\
\hline 11 & $\begin{array}{l}\text { Counceling } \\
\text { Guidance }\end{array}$ & Nur Hidayah, S.Pd & $\begin{array}{l}\text { Dwi Anie, S.Pd, M.Pd } \\
\text { Nandang S., S.Pd,M.Pd } \\
\text { Dian Pusparani, S.Pd }\end{array}$ \\
\hline 12 & Javanese Language & Dina Sulestasi, S.Pd & Lilik Poerwanti, S.Pd \\
\hline 13 & $\begin{array}{l}\text { Technology } \\
\text { Information and } \\
\text { Comunication }\end{array}$ & $\begin{array}{l}\text { Amalia Citra Prastiwi, } \\
\text { S.Pd }\end{array}$ & $\begin{array}{l}\text { Drs. A n w a r } \\
\text { El Yakim S,S.Pd }\end{array}$ \\
\hline
\end{tabular}

Second, making open class schedule. In every academic years, we make open class schedule. Open class schedule in academic year 2018-2019 follow : 
Table 3. Open Class Schedule

\begin{tabular}{|c|c|c|c|c|}
\hline No & Activities & Time & $\begin{array}{c}\text { Subject and } \\
\text { Model Teacher }\end{array}$ & Observer \\
\hline 1 & Open Class 1 & $\begin{array}{c}\text { August } \\
\text { Third week }\end{array}$ & $\begin{array}{c}\text { Science } \\
\text { (Titik Ngatmi Rusiani, } \\
\text { M.Pd) }\end{array}$ & $\begin{array}{l}\text { Drs.Heru S., M.Pd } \\
\text { Gianto,M.Pd } \\
\text { Siti Laila, S.Pd } \\
\text { Vita Yuanita, S.Pd }\end{array}$ \\
\hline 2 & Open Class 2 & $\begin{array}{l}\text { September } \\
\text { First week }\end{array}$ & $\begin{array}{c}\text { English } \\
\text { (M. Faridah,S.Pd) }\end{array}$ & $\begin{array}{l}\text { Amelia K., S.Pd } \\
\text { Ririn Indra K,S.Pd } \\
\text { Andis Erika, S.Pd } \\
\end{array}$ \\
\hline 3 & Open Class 3 & $\begin{array}{l}\text { September } \\
\text { Second } \\
\text { week }\end{array}$ & $\begin{array}{l}\text { Art and Culture } \\
\text { (Iman G., M.Pd) }\end{array}$ & $\begin{array}{l}\text { Puji H.,M.Pd } \\
\text { Ida Oelfijah, S.Pd }\end{array}$ \\
\hline 4 & Open Class 4 & $\begin{array}{l}\text { September } \\
\text { Third week }\end{array}$ & $\begin{array}{l}\text { Javanese Language } \\
\text { (Lilik P.,S.Pd) }\end{array}$ & $\begin{array}{l}\text { Drs. Sucipto } \\
\text { Dina S.,S.Pd }\end{array}$ \\
\hline 5 & Open Class 5 & $\begin{array}{c}\text { October } \\
\text { First week }\end{array}$ & $\begin{array}{c}\text { Indonesian Language } \\
\text { (Anthoneta, M.Pd) }\end{array}$ & $\begin{array}{l}\text { Dra. Marminah } \\
\text { El Yakim S, S.Pd } \\
\text { Nuryasih, S.Pd } \\
\text { Mustain, M.A }\end{array}$ \\
\hline 6 & Open Class 6 & $\begin{array}{l}\text { October } \\
\text { Second } \\
\text { week }\end{array}$ & $\begin{array}{c}\text { Sosial Science } \\
\text { (Endang S., M.Pd) }\end{array}$ & $\begin{array}{l}\text { Anies M.,M.Pd } \\
\text { Endang S,M.Pd } \\
\text { Tri Wahyu, M.Pd } \\
\text { Dra. Sudartik }\end{array}$ \\
\hline 7 & Open Class 7 & $\begin{array}{c}\text { October } \\
\text { Third week }\end{array}$ & $\begin{array}{c}\text { Civic } \\
\text { (Nur Ayati,M.Pd) }\end{array}$ & $\begin{array}{l}\text { Ida Oelfijah,S.Pd } \\
\text { Nur Ayati,M.Pd } \\
\text { Drs. Sucipto.MM }\end{array}$ \\
\hline 8 & Open Class 8 & $\begin{array}{c}\text { October } \\
\text { Fourth week }\end{array}$ & $\begin{array}{c}\text { Sport } \\
\text { (Imam Mahdi,S.Pd) }\end{array}$ & $\begin{array}{l}\text { M. Sofwan,M.Pd } \\
\text { Mursid W,S.Pd }\end{array}$ \\
\hline 9 & Open Class 9 & $\begin{array}{l}\text { November } \\
\text { First week }\end{array}$ & $\begin{array}{c}\text { Math } \\
\text { (Nur Indah, M.Pd) }\end{array}$ & $\begin{array}{l}\text { Drs. Anwar } \\
\text { Djoemadi, M.Pd } \\
\text { Abdul Manaf, S.Pd } \\
\text { Linda Dwi, S.Pd }\end{array}$ \\
\hline 10 & Open Class 10 & $\begin{array}{c}\text { November } \\
\text { Second } \\
\text { week }\end{array}$ & $\begin{array}{c}\text { Cullinary art } \\
\text { (Isang Yanuar, S.Pd) }\end{array}$ & $\begin{array}{l}\text { Tamamik,S.Pd } \\
\text { Titik Ngatmi } \\
\text { R.,M.Pd }\end{array}$ \\
\hline 11 & Open Class 11 & $\begin{array}{c}\text { January } \\
\text { Third week }\end{array}$ & $\begin{array}{c}\text { Islamic Religion } \\
\text { (Ainul Yaqin,S.Ag) }\end{array}$ & $\begin{array}{l}\text { Nurul Huda,S.Ag } \\
\text { Nur Ayati, M.Pd } \\
\text { Saifuddin } \\
\text { Zuhri,S.Pd }\end{array}$ \\
\hline 12 & Open Class 12 & $\begin{array}{c}\text { January } \\
\text { Fourth week }\end{array}$ & $\begin{array}{l}\text { Technology Information } \\
\text { and Comunication } \\
\text { (Kasin, S.Pd) }\end{array}$ & $\begin{array}{l}\text { Drs. Anwar } \\
\text { Amalia Citra } \\
\text { Prastiwi, S.Pd } \\
\text { Abdul Manaf, S.Pd } \\
\text { Iman Gunawan, } \\
\text { M.Pd }\end{array}$ \\
\hline 13 & Open Class 13 & $\begin{array}{c}\text { February } \\
\text { First week }\end{array}$ & $\begin{array}{l}\text { Counceling Guidance } \\
\text { (Nur Hidayah, M.Pd) }\end{array}$ & $\begin{array}{l}\text { Dwi Anie, S.Pd, } \\
\text { M.Pd } \\
\text { Nandang S., } \\
\text { S.Pd,M.Pd } \\
\text { Dian Pusparani, } \\
\text { S.Pd }\end{array}$ \\
\hline
\end{tabular}

\section{B. Innovation Class Based Lesson Study Activities}

1. The first stage

Planning Stage 
In the planning stage, every subjects teacher groups (MGMPS) meet and assessing curriculum core competencies/basic competencies (KI/KD), determine learning material, difficult material for students, material that requires effective methods, material that requires effective media, develop indicators, determine the method, determine the learning sequence (scenario), arranging student work sheet, develop evaluation, planning a research lesson.

The

question follows this could be reference: What are the current is understood by the students on the topic of this? What do we expect students to master at the end of the lesson? What a series of questions and or experience of learning the students that will encourage the students acquire knowledge of the curriculummore advanced? What activities are capable of motivating and meaningful for Students. What evidence about outcomes of learning of students, motivation of students, the behavior of students that must be collected for the data discussion at the time of reflection and how the collected instrument?

\section{Results of Planning Stage}

Lesson Plan, other learning tools (student work sheet, evaluation instruments), media / sources of learning, It was agreed upon as a model teacher.

\section{Second Stage}

Implementation Stage

In the implementation stage, the activities are: teacher models do learning and other teachers make observations in the class.

Teacher Model Activities

Prepare photocopies of lesson plan, student work sheet, media and learning resources, the room, classes naturally, doing learning as if he taught himself. Next, come no later than 20 minutes before, enter class on time, start learning by explaining the presence of observers, convey learning objectives / indicators, motivate students to start learning, applying lesson plan and student work sheet as planned, but the teacher can change the scenario according to circumstances, active and creative learning oriented students, motivating students to learn from each other. Although collaborating, the results are individual if discussing, form a maximum group of heterogeneous members, respect the right of every student to study. The teacher stands in the front corner observing students, trying to find students who have difficulty learning and helping them. The teacher goes around to groups if a discussion group is completed first, give it a sieve. The teacher invites students to present if the presentation is the same and students are bored, then replace it with a question and answer. The teacher ends the lesson on time.

\section{Observation Activities}

Everyone immediately entered the classroom in an orderly manner at the proper time. When entering the room all the participants and the invitation should be no more disposition and out of the classroom. As soon occupy a position so that it can pay attention to changes in his facial expressions and gestures of students when learning. In the beginning, each trained observer observing one group. Does not help the teacher in the learning process in any form. Do not help the student in the learning process. Does not interfere with the views of the teacher / student during learning. Does not interfere with students' concentration in learning, for example talking to other observers, going in 
and out of the room. If using a camera flash (flash) should be turned off. Do not eat, drink and smoke in the room learning. Remember, focus on observing students learning, not only on teachers who teach. Observers to observe in full from the beginning to the end of learning. Besides observing student learning, observers also need to pay attention to class management techniques made by the teacher, how can the teacher streamline the achievement of learning objectives, how do teachers use simple learning media from the environment and how do teacher make creative students.

\section{3, Third Stage}

Stage of Reflection

Discussion examines data findings during observation. Analyze why it happened and the way out. Reflection is done immediately after learning. Reflection rooms should contain only 5 - 10 peoples arranged in a U-shape. Appoint a moderator. Appoint a reporter. Moderators lead reflection. Observer signs in submitting comments. Observation signs in submitting comments: Comments submitted should be focused on the issue of student learning process, rather than on the activity of teachers in teaching. Comments submitted must be based on the current observational data observation and not based on the desire of the observer. Use of the word "teaching us" to comment on the learning process. Use a soft tone and choice of words are smooth. Comments submitted should be far from being "patronizing" or in his own eyes. If the delivered data about student learning, point out why it happened and how to get out. Indicate also what lessons can be learned from these problems.

\section{Data Analysis Techniques}

Data analysis techniques are intended to find answers to research questions or about problems that have been previously formulated. The approach used in this research is a quantitative approach, then the data analysis used is a statistical data analysis technique.

\section{FINDING AND DISCUSSION}

The implementation of Lesson Study in SMP Negeri 2 Menganti this year enters its nineth year. In the second year there was mentoring program from Malang State University. In the third year until now there was no mentoring program from Malang State University again but Lesson Study activities at State Middle School 2 Menganti continued well. The mentoring program from Malang State University gives more insight, knowledge, enthusiasm to move forward to improve the quality of education in State Middle School Menganti 2.

After we conducted Lesson Study activities for many years, we have felt so many benefits to improve the quality of education in our school. advised that more mentoring visits to our schools give us more knowledgeable and more enthusiastic in improving the quality of education in our schools.

Lesson Study based innovation class in our school had increase student outcome. The increasing can be seen from values examination. The values examination increase in few years. Lesson study base innovation class makes students abble to be active and creative students so they are often to be the winners in many competition as Sport competition, Art competition, Math competition, Science competition, English competition, and etc. 
Lesson Study based innovation class in our school had increase quality of teachers. The increasing can be seen from competitions that the teachers follow. Few of teachers can be winners in competition Math, Social Science, Science, English, Indonesian language, and etc.

\section{CONCLUSIONS}

When looking at the results of the data analysis above, it appears that the the implementation of Lesson Study gives more insight, knowledge, enthusiasm to move forward to improve the quality of education in State Middle School Menganti 2. After we conducted Lesson Study activities for many years, we have felt so many benefits to improve the quality of education in our school. advised that more mentoring visits to our schools give us more knowledgeable and more enthusiastic in improving the quality of education in our schools.

Lesson Study based innovation class in our school had increase student outcome. The increasing can be seen from values examination. The values examination increase in few years. Lesson study base innovation class makes students abble to be active and creative students so they are often to be the winners in many competition as Sport competition, Art competition, Math competition, Science competition, English competition, and etc. Lesson Study based innovation class in our school had increase quality of teachers. The increasing can be seen from competitions that the teachers follow. Few of teachers can be winners in competition Math, Social Science, Science, English, Indonesian language, and etc.

\section{REFERENCES}

Istamar Syamsuri and Ibrohim. 2008. Lesson study (Study Learning): Model Pembimbingan Pendidik learned from experience Lesson study in the Program Implementation SISTTEMS JICA in Pasuruan. Malang: FMIPA UM

Liliasari. 2008. Teacher Professional Development through Chemistry Education Lesson study at Tanjungsari. Paper in the International Conference on Lesson study. Bandung, July 31 - August 1.

Lewis, CC 2002. Lesson study: A Handbook of Teacher-Led Instructional Change. Philadelphia: Reseach For better School .Inc.

Lewis, C. Perry, R. Dan Murata, A., 2006. How Should the Research Contribute to Instructional Improvement: The Case of Lesson Study. Educational Researcher, 35 ( 3) : 3-14.

Ministry of National Education, 2005. Strategic Plan of the Ministry of National Education 2005-2009 Towards Long-Term National Education Development. Jakarta: Ministry of National Education

Saito, E., 2005. Changing Lessons, Changing Learning: Case Study of Piloting Activities under IMSTEP. Proceedings of the MIPA National Seminar and Learning \& Exchange Experience of IMSTEP. Malang, 5-6 September.

Saito, E., Harun, I., and Ibrohim. 2005. Application of Learning Studies in Indonesia: Case Study from IMSTEP. Educational Pulpit Journal, 3 (24): 24-32. 43 -49.

Sumarna. 2006. Implementation of School-Based Study Lesson to Improve Biology Teachers' Ability to Conduct Innovative Learning. Booklet of the National Seminar on Research, Education and Implementation of MIPA. Yoyakarta, August 1. 